\title{
Chemical, physical, and optical evolution of biomass burning aerosols: a case study
}

\author{
G. Adler ${ }^{1}$, J. M. Flores ${ }^{2,3}$, A. Abo Riziq ${ }^{1}$, S. Borrmann ${ }^{2,3}$, and Y. Rudich ${ }^{1}$ \\ ${ }^{1}$ Department of Environmental Sciences, Weizmann Institute of Science, Rehovot 76100, Israel \\ ${ }^{2}$ Department of Particle Chemistry, Max Planck Institute for Chemistry, Mainz 55128, Germany \\ ${ }^{3}$ University of Mainz, Institute for Atmospheric Physics, Mainz 55099, Germany
}

\begin{abstract}
In-situ chemical composition measurements of ambient aerosols have been used for characterizing the evolution of submicron aerosols from a large anthropogenic biomass burning (BB) event in Israel. A high resolution Time of Flight Aerosol Mass Spectrometer (HR-RES-TOFAMS) was used to follow the chemical evolution of BB aerosols during a night-long, extensive nationwide wood burning event and during the following day. While these types of extensive BB events are not common in this region, burning of agricultural waste is a common practice. The aging process of the $\mathrm{BB}$ aerosols was followed through their chemical, physical and optical properties. Mass spectrometric analysis of the aerosol organic component showed that aerosol aging is characterized by shifting from less oxidized fresh $\mathrm{BB}$ aerosols to more oxidized aerosols. Evidence for aerosol aging during the day following the $\mathrm{BB}$ event was indicated by an increase in the organic mass, its oxidation state, the total aerosol concentration, and a shift in the modal particle diameter. The effective broadband refractive index (EBRI) was derived using a white light optical particle counter (WELAS). The average EBRI for a mixed population of aerosols dominated by open fires was $m=$ $1.53( \pm 0.03)+0.07 i( \pm 0.03)$, during the smoldering phase of the fires we found the EBRI to be $m=1.54( \pm 0.01)+$ $0.04 i( \pm 0.01)$ compared to $m=1.49( \pm 0.01)+0.02 i( \pm 0.01)$ of the aged aerosols during the following day. This change indicates a decrease in the overall aerosol absorption and scattering. Elevated levels of particulate Polycyclic Aromatic Hydrocarbons (PAHs) were detected during the entire event, which suggest possible implications for human health during such extensive event.
\end{abstract}

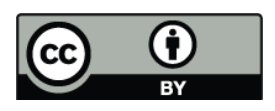

Correspondence to: Y. Rudich (yinon.rudich@weizmann.ac.il)

\section{Introduction}

Biomass burning aerosols are a product of natural fires and human-induced burning, such as wood or agricultural waste. About $40 \%$ of global emission of BC is originate from biomass burning (Bond et al., 2004). Biomass burning aerosols contain, among other compounds, nitrate, ammonium, sulfur, organic components and black carbon (Andreae et al., 2001). BB aerosol may have a significant impact on regional air quality, visibility, cloud processes, human health, global and regional climate (Reid et al., 2005; bin Abas et al., 2004; Pope, 2000; Gustafsson et al., 2009; Koren et al., 2004; Spracklen et al., 2007; Zhang et al., 2007).

Biomass burning can be a source of primary organic aerosols, which make up a large fraction $(20-90 \%)$ of the submicron particulate matter (Zhang et al., 2007; Murphy et al., 2006). In the atmosphere, aerosols evolve and participate in photochemical oxidation processes (Rudich et al., 2007; $\mathrm{Ng}$ et al., 2010; Jimenez et al., 2009). The atmospheric evolution (also known as "aging") of biomass burning aerosols and its consequences remains poorly characterized (Zhang et al., 2007; Murphy et al., 2006) and warrants a better understanding of the chemical and physical evolution of organic aerosols (Kiehl, 2007). This study aims to provide a detailed look at the aging process of an intensive biomass burning event in an urban environment by examining the changes in chemical composition, physical and optical properties of the emitted aerosols as they age, initially during night and then during a few hours of day time.

The High Resolution Time of Flight Aerodyne Aerosol Mass Spectrometer (AMS ) was used to provide quantitative data on the organic aerosol composition and its evolution (DeCarlo et al., 2006). Recent AMS studies divide the organic aerosols into two main components: hydrocarbonlike organic aerosol (HOA) and oxygenated organic aerosol (OOA) (Zhang et al., 2007). A clear correlation was found between secondary species such as $\mathrm{O}_{3}, \mathrm{NO}_{\mathrm{x}}$ and $\mathrm{OOA}$

Published by Copernicus Publications on behalf of the European Geosciences Union. 
component (Zhang et al., 2005; Herndon et al., 2008). The OOA can be divided into two major groups according to the degree of volatility and the level of oxidation (Lanz et al., 2007). The more oxidized component is called low-volatility OOA (LV-OOA), while the less oxidized component is referred to as semi-volatile OOA (SV-OOA) (Jimenez et al., 2009). Ng et al. (2010) identify the more oxidized component (LV-OOA), with higher $f 44$ (the organic ion signal intensity measured at $m / z=44$ normalized to the total signal intensity originating from particulate organics), while the less oxidized component (SV-OOA) is characterized with lower $f 44$.

In this study we focus on the evolution of few significant ions the $\mathrm{m} / \mathrm{z}, 43,44,57,60$ and 73 , in order to identify biomass burning aerosols and follow their evolution during the burning event and after. The $\mathrm{m} / \mathrm{z} 43,44$, and 57 ions were used to follow the aging process and estimate the degree of oxidation, while $\mathrm{m} / \mathrm{z} 60$ and 73 were used as markers for wood burning aerosols (Alfarra et al., 2007). Specifically, in this study, the $m / z 43$ fragment ion corresponds mainly to $\mathrm{C}_{2} \mathrm{H}_{3} \mathrm{O}^{+}$and $\mathrm{C}_{3} \mathrm{H}_{7}^{+}$, while the $m / z 57$ was found to be correlated with $\mathrm{C}_{4} \mathrm{H}_{9}^{+}$and $\mathrm{C}_{3} \mathrm{H}_{5} \mathrm{O}^{+}$. In previous studies, the $\mathrm{m} / \mathrm{z}$ 44 was shown to be related to the $\mathrm{CO}_{2}^{+}$ion (Alfarra et al., 2004). An increase in the $f 44$ and a decrease in the $f 43$ can indicate oxidation. For biomass burning indication, the fragment ions $m / z 60\left(\mathrm{C}_{2} \mathrm{H}_{4} \mathrm{O}_{2}^{+}\right)$and $m / z 73\left(\mathrm{C}_{3} \mathrm{H}_{5} \mathrm{O}_{2}^{+}\right)$were used, since $m / z 60,73$ and 137 have been suggested as marker fragments for wood burning emissions (Alfarra et al., 2007).

Atmospheric aging also affects the physical properties of the aerosols. Dubovik et al. (2002) and Heywood et al. (2003) found that the mean aerosol radius increases with aging. Moreover, the optical properties of aerosols can also change upon aging (Jacobson, 1999; Lelieveld et al., 2002). The direct impact of aerosols on Earth's radiative budget is driven by their optical properties, specifically, the scattering and absorption components of the refractive index, which, is a key parameter in modeling their radiative effect. Simultaneous measurements of ground-based and airborne lidars during the Lindenberg Aerosol Characterization Experiment (LACE 98), reported complex refractive indices for biomass burning aerosols from forest fires in northern Canada of $1.56-1.66$ for the real part and $0.05-0.07 i$ for the imaginary part (Wandinger et al., 2002). While the optical properties of aged biomass burning aerosol reported a complex refractive index of $n=1.54+0.045 i$ (Johnson et al., 2008), and of $n=1.54+0.018 i$ at $550 \mathrm{~nm}$ (Haywood et al., 2003).

Additionally, biomass burning aerosols can have a significant effect on human health since fine particles can efficiently penetrate the alveolus (Asgharian et al., 2001), delivering toxic components such as polycyclic aromatic hydrocarbons (PAHs), which form during the burning or pyrolysis of organic matter. Particle-bound can induce allergenic, mutagenic, and carcinogenic response (Asgharian et al., 2001; Pope, 2004; Pöschl, 2002; Schauer et al., 2003). Common PAHs in biomass burning smoke are naphthalene, acenaphthene, fluorene, phenanthrene, anthracene, fluoranthene, pyrene, benzo(a)pyrene and fluoranthene (Hedberg et al., 2002). The last two compounds and their metabolites are strong carcinogens (Hedberg et al., 2002). Studies which investigated the atmospheric evolution of wood burning aerosol suggested that metoxyphenols in the aerosols could enhance the photochemical degradation of PAHs (Krzyzanowski et al., 2005; Vione et al., 2006; Wichmann, 2000). Furthermore, it has been suggested that it is essential to consider the atmospheric evolution of the emitted wood smoke aerosols in order to elucidate the potential health effect (Bolling et al., 2009).

The key for evaluating the effect of biomass burning aerosols on climate and human health depends on our understanding of their chemical and physical properties (size, morphology and optical properties). This study investigates the chemical and physical transformation of freshly emitted biomass burning aerosols which were sampled during an extensive nationwide wood burning event (named Lag BaOmer-LBO) which took place between the 11 and 12 May 2009. In this national Israeli holiday, people ignite thousands of bonfires in open spaces in cities and towns throughout the entire country. The event starts at sunset (around 19:30 local time), but most of the bonfires begin later. The event officially ends by sunrise; however, most of the fires are extinguished beforehand. The $\mathrm{PM}_{10}$ values during the burning event were on average of $150 \mu \mathrm{g} \mathrm{m}^{-3}$ (measured by a station located $800 \mathrm{~m}$ from the site) compared to a normal day in which the average $\mathrm{PM}_{10}$ values are around $25 \mu \mathrm{g} \mathrm{m}^{-3}$. In this study we followed the biomass burning event and the contributions of primary submicron (POA) and secondary submicron organic aerosol (SOA) to the regional mass loading. This was done using mass spectrometric measurements of the non-refractory components. The study examines the chemical aging and optical properties of these aerosols during and after the burning event.

\section{Methodology}

The measurements took place between the 11 and 12 May 2009 in an urban area on the roof of a 4 story building located in the Weizmann Institute of Science in Rehovot, Israel $\left(31^{\circ} 53^{\prime} \mathrm{N}\right.$. $34^{\circ} 48^{\prime \prime} \mathrm{E}$.). The chemical properties of the non refractory submicron diameter aerosols were sampled using a Time of Flight Aerosol Mass Spectrometer (TOFAMS, Aerodyne). The size distributions and particle number concentration for aerosol particles with a diameter below $700 \mathrm{~nm}$ were measured using a Scanning Mobility Particle Sizer (SMPS, TSI model 3080). A Condensation Particle Counter (CPC, TSI 3022) was used for counting particles with diameter larger than $7 \mathrm{~nm}$. The three instruments were located on the third floor; a sampling line of $3 / 8$ conductive silicone rubber tubing from the roof to the instruments was 
used for sampling. The flow was split and sampled by the SMPS and by the AMS and CPC. The TOF-AMS sampled at a constant flow of $80 \mathrm{~cm}^{3} \mathrm{~min}^{-1}$, while the SMPS and the CPC have constant flow of $300 \mathrm{~cm}^{3} \mathrm{~min}^{-1}$ each. The particle loss calculator (von der Weiden et al., 2009) was used in order to estimate the particle losses via the tubing. The lengths of the tubes as well as the angles of curvature were taken into account. The maximum loss was found to be $6.5 \%$ for $700 \mathrm{~nm}$ particle. These losses were taken into account in all the calculations presented in this paper. The SMPS performed a measurement every $5 \mathrm{~min}$, the HR-TOF-AMS was set to measure $1 \mathrm{~min}$ average, while the CPC sampled continuously.

A White Light Aerosol Spectrometer (WELAS, PALAS Gmbh, Karlsruhe) at the roof sampled the aerosols directly $\left(5 \mathrm{~L} \mathrm{~min}^{-1}\right)$, providing optical size distributions for $0.3 \mu \mathrm{m}$ to $10 \mu \mathrm{m}$ diameter ranging between every 2 minutes. In addition, ozone concentration and meteorological data from an air quality monitoring network, which belongs to the ministry of environmental protection of Israel; located some $800 \mathrm{~m}$ from the campaign site was used

\section{HR-ToF-AMS measurements of particle chemical composition}

The HR-ToF-AMS is described in detail in DeCarlo et al. (2006). The HR-ToF-AMS operated in the V-mode, which is more sensitive but has lower mass resolution compared to the $\mathrm{W}$-mode. The one minute detection limit of the $\mathrm{V}$-mode for all species is $<0.04 \mu \mathrm{g} \mathrm{m}^{-3}$ (DeCarlo et al., 2006). The results presented here were primarily obtained using both the mass spectrum (MS) and the particle time of flight (PTOF) modes. The time series of organic/inorganic species and PAHs specifically were determined from total mass spectra by application of the "fragmentation table" introduced by Allan et al. (2004) and using the Squirrel analysis software (v1.47).

A collection efficiency of 0.5 was assumed throughout this study, which is typical for dry particles (Matthew et al., 2008); this assumption is possibly more accurate towards the end of the burning event as well as in the following days, since the sampled aerosols were not dried. The relative humidity (RH) was around $50-60 \%$ at the end of the burning event, compared to $70-85 \%$ during the burning event itself. However, fresh biomass burning aerosols are highly hydrophobic at these levels of RH (Hand and Kreidenweis, 2010; Wiechmann et al., 2000).

The ionization efficiency (IE) of nitrate was determined using pure ammonium nitrate particles, while for all other species relative ion efficiencies (RIE) were adopted from previous laboratory studies (Alfarra et al., 2004). The vacuum aerodynamic diameter measurement was calibrated with size-selected ammonium nitrate particles and with polystyrene latex (PSL) spheres of known diameters between 50 and $600 \mathrm{~nm}$.

\section{The WELAS optical measurements of particle size and number concentration}

The white light optical particle counter (WELAS; PALAS Gmbh, Karlsruhe) was used to measure the optical size distribution of the ambient aerosols and to derive the effective broadband refractive index (EBRI) of the aerosols (Flores et al., 2009). Only a brief description of the WELAS is given in this manuscript and a detailed description is given elsewhere Heim et al. (2008). The WELAS measures particles between $300 \mathrm{~nm}$ and $10 \mu \mathrm{m}$. It is a white light (Osram Xenarc $4200 \mathrm{~K}$, the spectrum of the white light ranges from 370 to $780 \mathrm{~nm}$.) optical particle counter that collects scattered light at a $90^{\circ}$ mean angle. The scattered light is binned into one of 4095 channels depending on the intensity of the light measured by a photomultiplier, and a corresponding size is assigned to every channel by comparison to a calibration curve which is based on a calibration dust (CalDust 1100), which has the same index of refraction as polystyrene latex spheres (Flores et al., 2009).

Inherently, size determination of the scattering particle is highly dependent on the complex refractive index of the aerosol particles. Hand and Kreidenweis (2002) used this dependency to show that by aligning the size distribution of an optical particle counter to that of the SMPS (in their overlap region) a refractive index can be derived. However, theoretical calibration curves need to be created to correctly map the detected size distribution onto the ambient size distribution. Flores et al. (2009) developed the method to obtain these calibration curves for the WELAS and to derive the "effective broadband refractive index". It is retrieved by matching the optical size distribution of the WELAS with that measured by a scanning mobility particle sizer (SMPS) assuming spherical particles (Flores et al., 2009). The term "effective" is used as it is assumed the particle's chemical composition and morphology to be independent of particle size. The term "broadband" indicates an average over the wavelengths in the visible range. It was previously shown that the EBRI represents well aerosols that scatter and absorb throughout the visible range, but does not provide a good presentation of particles with strong wavelength-dependent refractive index, such as "brown carbon" (Flores et al., 2009). As a caveat we emphasize that it is applied here for the first time for nonspherical particles, mostly during the intensive fires. Numerical calibration curves for refractive indices from a real component of 1.3 to 1.7 in 0.01 steps, and the imaginary part from $0.05 i$ to $0.3 i$ in 0.01 steps were used. The WELAS size distributions were cut for particles above $1 \mu \mathrm{m}$ diameter to match the calibration curves, and the population of particles greater than $1 \mu$ mcan vary significantly in composition and morphology from the accumulation mode population. 


\section{Results and discussion}

This is the first AMS field deployment in the Middle East region for studying an intensive nationwide biomass burning and background aerosols. The fires were initiated after sunset and the study followed the aerosol evolution from the onset of fires for about $18 \mathrm{~h}$, until noon the next day. While this type of massive biomass burning is not common in this region, burning of agricultural waste is a common practice in this region (Sarnat, 2010). Figure 1 shows the time series of the meteorological conditions as measured by a station located $800 \mathrm{~m}$ from the measurement site, as well as the organics mass and the particle concentration to provide a timeline of the event. The marked areas represent the burning event itself (Period A) compared to the aged aerosols at noon of the following day (Period B). A main concern was to verify that the aerosols studied in Period B were aged biomass burning aerosols and not a different population of aerosols. To establish this, we first analyzed the meteorological conditions during the measurement period. The barometric pressure as shown in Fig. 1 was stable (1013-1014 mb), and the wind speed was very low during the event (around $1 \mathrm{~ms}^{-1}$ ); it increased slightly $\left(3-5 \mathrm{~ms}^{-1}\right)$ at period B. During Period A there were south-easterly winds leading to the advection of the aerosol plume from the sampling location towards the Tel Aviv area, the most populated area in Israel (with large number of bonfires). At around 08:00 a.m. the wind changed direction possibly returning the air mass to the sampling site. Additional evidence for period B having the same population of particles is based on the chemical analysis, as discussed later.

\section{Chemical markers in the biomass burning aerosols}

\subsection{Biomass burning markers}

The mass fragments 60, 73 were suggested as specific marker fragments for wood burning aerosols (Alfarra et al., 2007). $\mathrm{m} / \mathrm{z}, 60$ and 73 were detected in the aerosols during the open fires stage, smoldering and in the aged aerosols (Period A and B). It can be seen in Fig. 2 that $m / z, 60$ follows the same pattern as the organics at the burning event and in Period B. The presence of $m / z 60$ (which is used as a marker for wood burning) in the aerosols at this period is a base for an assumption that Period B contains aged BB particles.

The $f 60$ (the organic ion signal intensity measured at the $\mathrm{m} / \mathrm{z}, 60$ line normalized to the total signal intensity originating from particulate organics) is in its highest value at the burning/smoldering period, and decreases in the following day as expected. This tendency is also seen in the mass spectra (Fig. 2) which show a decrease in the dominance of $\mathrm{m} / \mathrm{z}$ 60 and $\mathrm{m} / \mathrm{z}, 73$ at the day following the burning event. The highest level of f60 is in the smoldering phase (Midnight to 03:00 a.m. 12 May 2009), in a good agreement with pre-

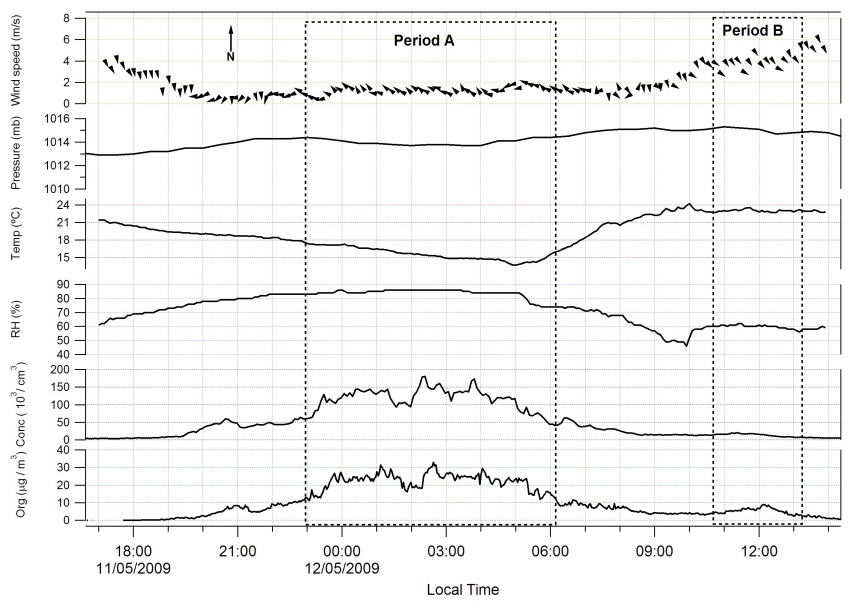

Fig. 1. The time series of the mass concentration of organics $\left(\mu \mathrm{g} \mathrm{m}^{-3}\right)$ and the particle number concentration $\left(\mathrm{cm}^{-3}\right)$, are presented at two marked areas representing the burning event (Period $\mathrm{A})$, and the following day at noon (Period B). The corresponding meteorological conditions (i.e. Temp $\left(\mathrm{C}^{\circ}\right)$, barometric pressure $(\mathrm{mb})$, the wind speed $\left(\mathrm{ms}^{-1}\right)$ and wind direction) are presented as well. The average error of the organic mass is $0.025 \mu \mathrm{m} \mathrm{m}^{-3}$ for part A and $0.019 \mu \mathrm{m} \mathrm{m}^{-3}$ for part B.

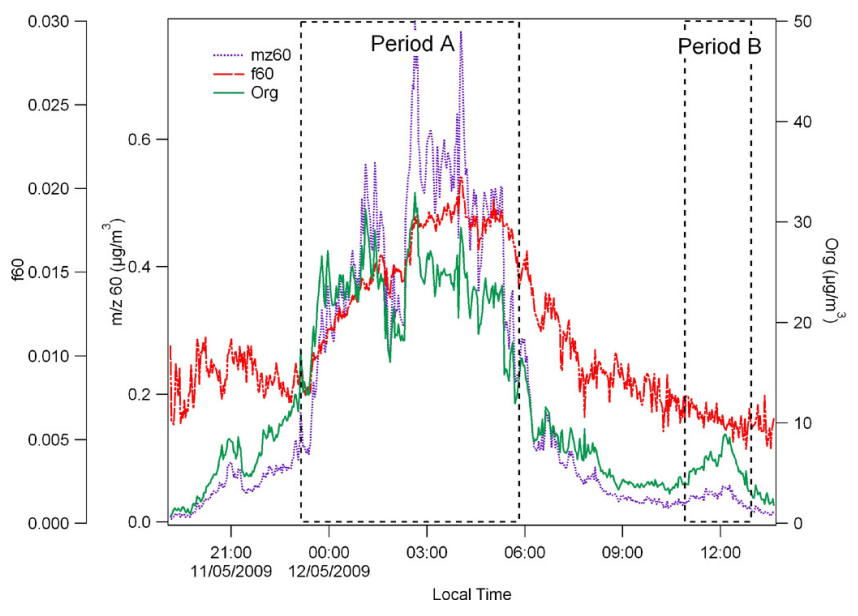

Fig. 2. The organics mass concentration, $m / z 60$ (used as a marker for wood burning) and $f 60(\mathrm{~m} / \mathrm{z} 60$ normalized by the organics) plotted as a function of time, including the burning event as well as during the following day. Local time is shown.

vious studies (Schkolnik et al., 2005). The $f 60$ during period A ranged between 0.01 and 0.021 . These values are in good agreement with a recent study reporting that the ratio of $\mathrm{m} / \mathrm{z} 60$ signal to OA during biomass burning ranges between 0.012 and 0.057 (He et al., 2010). 


\subsection{Polycyclic aromatic hydrocarbons (PAHS)}

Figure 3 shows the average normalized mass spectra of PAHs during the biomass burning event (averaged over $\sim 7 \mathrm{~h}$ 12 May 2009), and during a normal day in the same urban area, in 16-17 May 2009 (averaged over 24h). Both mass spectra were normalized to the sum of the total PAH of both periods (A and C), the PAHs analysis was done by updating the fragmentation table following Dzepina et al. (2007), and the relative ionization efficiency was taken as 1.4.

The mass spectra during burning show a clear dominance of $\mathrm{m} / \mathrm{z} \quad 202 \quad\left(\mathrm{C}_{6} \mathrm{H}_{10}\right.$-Pyrene $), \quad \mathrm{m} / \mathrm{z} \quad 226$ $\left(\mathrm{C}_{18} \mathrm{H}_{10}\right.$-Cyclopenta[cd]pyrene), $\quad m / z \quad 240 \quad\left(\mathrm{C}_{19} \mathrm{H}_{12}-\right.$ Methylbenzo[ghi]fluoranthene), $\quad m / z \quad 276 \quad\left(\mathrm{C}_{22} \mathrm{H}_{12}-\right.$ Benzo[ghi]perylene), $m / z \quad 300\left(\mathrm{C}_{24} \mathrm{H}_{12}\right.$-Coronene). The averaged total concentration of the PAHs measured in the burning event was $341 \pm 44 \mathrm{ng} \mathrm{m}^{-3}$. This is a high loading, which can be compared to $177 \mathrm{ngm}^{-3}$ with a peak of 1995 $\mathrm{ng} \mathrm{m}^{-3}$ during rush hour in Mexico City (MCMA-2003 campaign) (Dzepina et al., 2007). During normal days, the PAH mass concentration level measured was $80 \pm 15 \mathrm{ng} \mathrm{m}^{-3}$. In a normal day the PAH with highest concentration was found to be $m / z 202\left(\mathrm{C}_{6} \mathrm{H}_{10}\right.$-Pyrene), in good agreement with the reported values of MCMA-2003 campaign (Dzepina et al., 2007). The high concentrations of PAHs observed for many hours during burning and smoldering phases suggest that such events may pose public health hazard.

The presence of PAHs such as $m / z 202\left(\mathrm{C}_{6} \mathrm{H}_{10}\right.$-Pyrene $)$ are used to establish that the particles measured in the day following the burning event are aged BB aerosols, since as seen in Fig. 4 the $m / z 202$ follows the organics trend line, at the burning event and at the following day (Period B).

\subsection{Chemical aging of biomass burning aerosol}

The presence of aged BB aerosols during the following day is established by observing the main AMS-identified functional groups of the biomass aerosols. Two HR-TOF-AMS mass spectra normalized to the total organics of the whole event are presented in Fig. 5, illustrating the chemical aging process of the aerosols. The normalized mass spectrum (organic part only) shown in Fig. 5a is an average over $\sim 7 \mathrm{~h}$ of the nighttime peak of the biomass burning event (Period A), Fig. 5b shows the normalized mass spectrum (organic part only) of the day following the burning event, averaged over $\sim 2 \mathrm{~h}$ (Period B). Period A represents freshly emitted biomass burning aerosols while Period B represents aged aerosol. Both periods were normalized to the total organics of the whole event (average over $19 \mathrm{~h}$ ), specifically, $\mathrm{m} / \mathrm{z} 44$ and $\mathrm{m} / \mathrm{z} 18$ are related to the $\mathrm{CO}_{2}^{+}$and $\mathrm{H}_{2} \mathrm{O}^{+}$ions respectively, attributed to decarboxylation due to the thermal breakdown of diacids, $\omega$-oxocarboxylic acids and $(\omega$ oxoacids) containing carboxyl and aldehyde groups (Alfarra et al., 2007, 2004) at the vaporizer of the AMS. They are considered the most reliable markers of oxygenated organic aerosol (Zhang et al., 2005b).
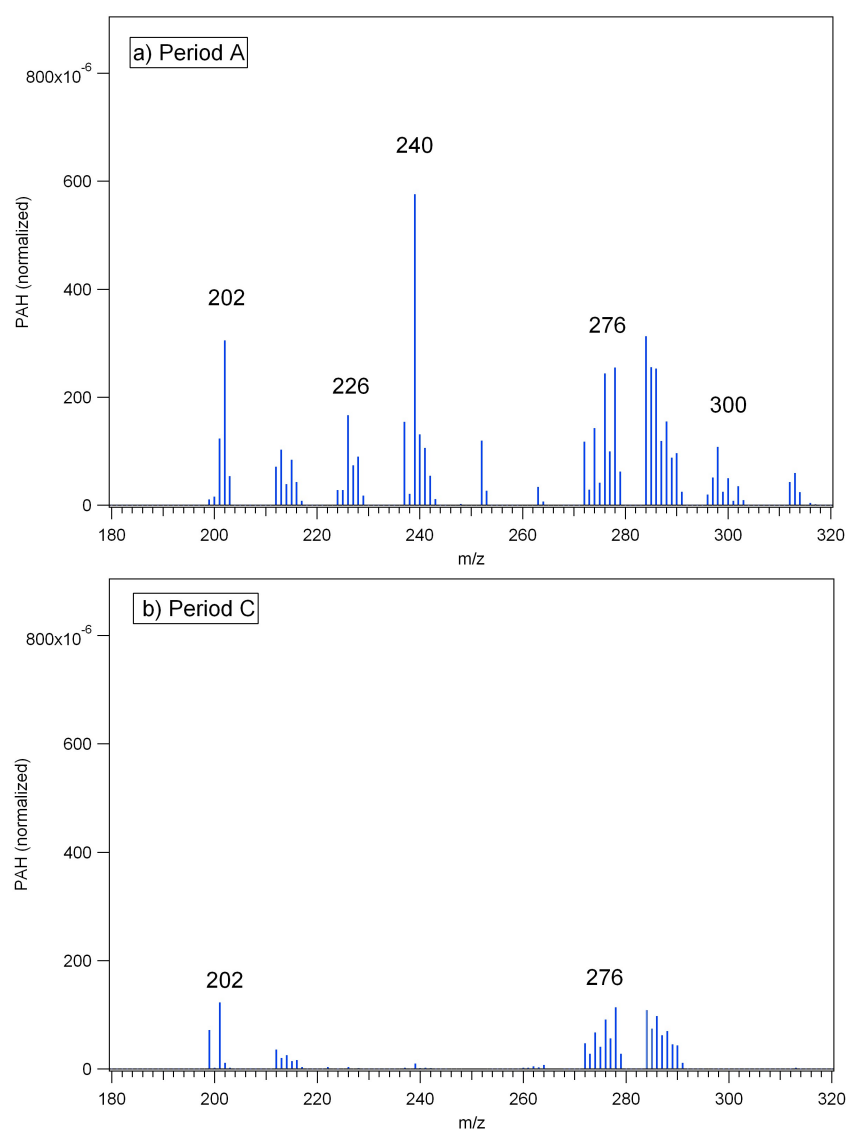

Fig. 3. Average mass spectra of PAHs in 2 different periods: during the biomass burning event (period A), and a few days after the burning event (Period C); normalized to the sum of the total PAH of both measured periods (A and C). The burning event was averaged over $\sim 7 \mathrm{~h}$ (12 May 2009), and the a normal day was averaged over 24 h (16-17 May 2009).

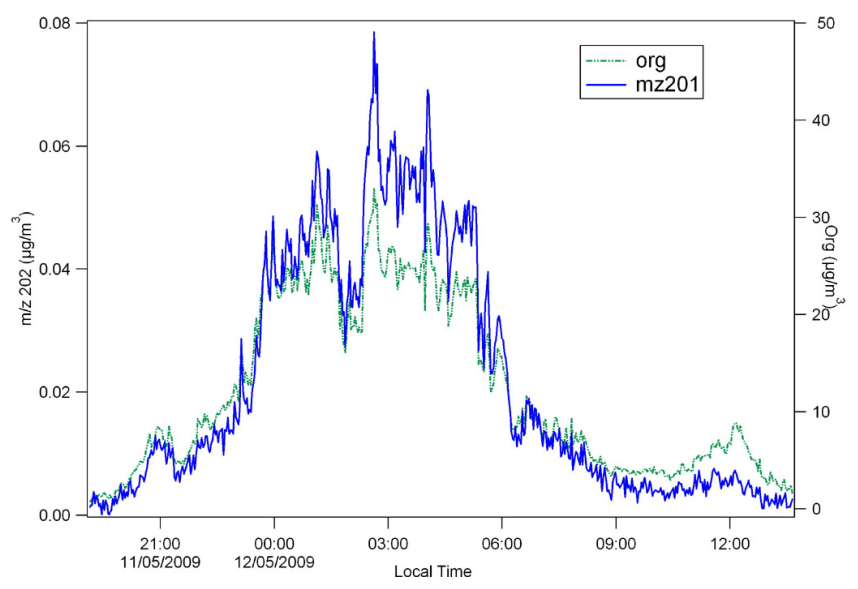

Fig. 4. The organic mass concentration, $m / z 202$ (mainly $\mathrm{C}_{6} \mathrm{H}_{10^{-}}$ Pyrene) concentrations as a function of local time during the burning event and at noon the following day. 

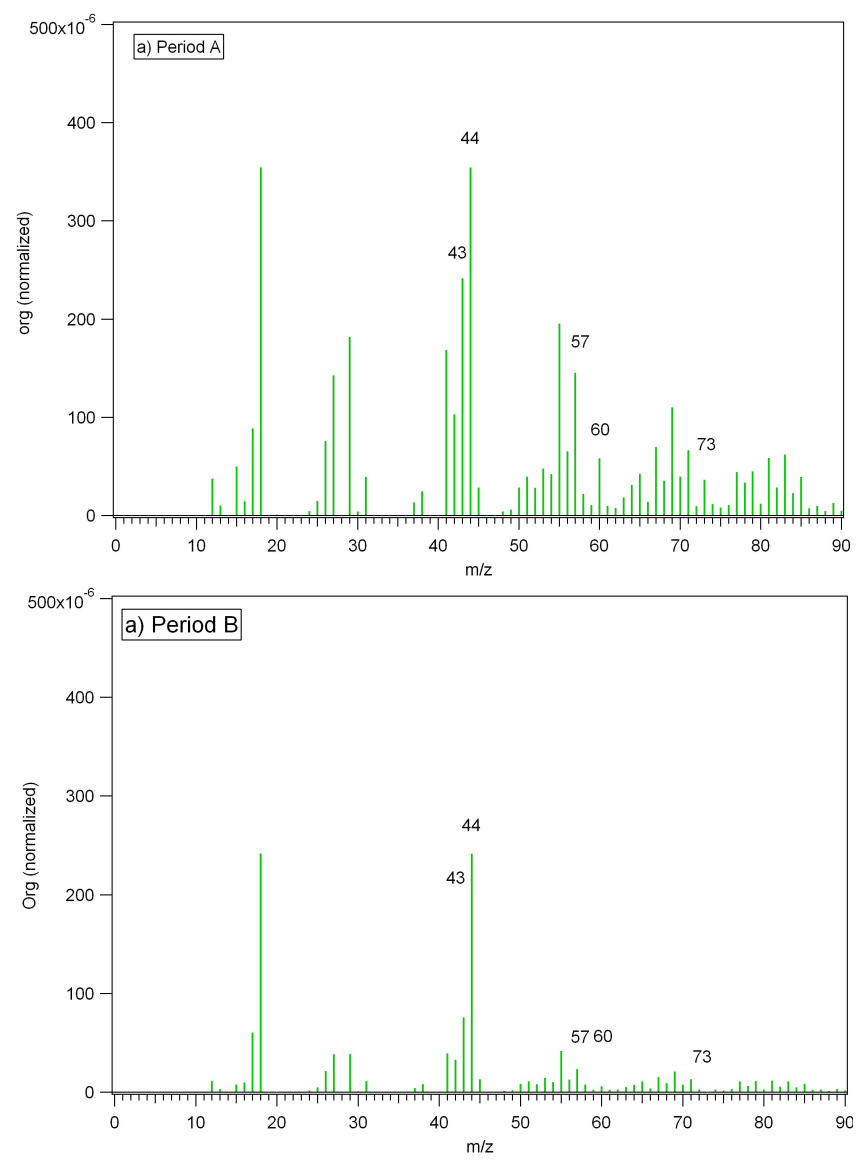

Fig. 5. Average mass spectra of organics, at the two different time periods: (a) Period A- during the biomass burning event, (b) Period B- after the burning event at noon time; Normalized to the total organic of the whole event (starting at the burning event till the day after).

The $m / z \quad 43$ corresponds mainly to $\mathrm{C}_{2} \mathrm{H}_{3} \mathrm{O}^{+}$and $\mathrm{C}_{3} \mathrm{H}_{7}^{+}$ fragments from both saturated hydrocarbons and oxidized species such as aldehydes and ketones. The $m / z, 43$ can be used as a marker for non-acidic oxygenates ( $\mathrm{Ng}$ et al., 2010).

The $m / z 57$ is a typical fragment of saturated hydrocarbons $\left(\mathrm{C}_{4} \mathrm{H}_{9}^{+}\right)$or long alkyl chains $\left(\mathrm{C}_{3} \mathrm{H}_{5} \mathrm{O}^{+}\right)$, the latter indicates oxidized organic compounds and is one of the common fragments of Levoglucosan.

Previous studies used the $m / z, 44$ signal to assess the degree of oxidation of organic aerosols (Takegawa et al., 2005). Figure 6 shows the mass concentration of $\mathrm{m} / \mathrm{z} 44$ plotted versus the total organics mass concentration for the burning event (Period A) and the following day (Period B). The slope represents the percentage of the $m / z 44$ signal of the total organics $(\Delta m / z 44 / \Delta$ org $)$. Two populations appear in the graph; meaning that the percentage of the $m / z$, 44 of the organics was different but constant during the two periods. During the burning event the slope was smaller than during the following day (slope $=0.060 \pm 0.001$, slope $=0.200 \pm 0.004$, respec-

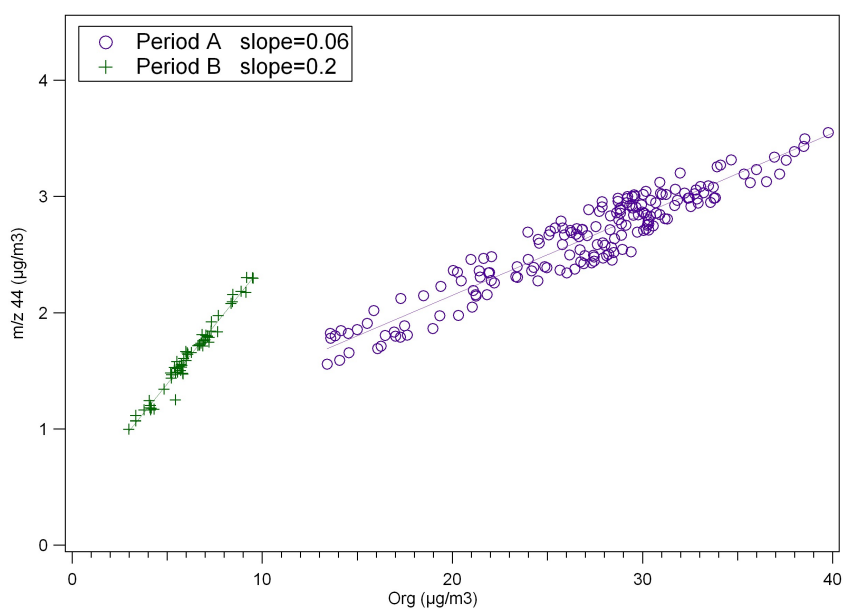

Fig. 6. $m / z, 44$ vs. the total organics at the two periods. Period A: the burning event (marked by purple circles) characterized by freshly emitted aerosols. Period B: the following day at noon (marked by green crosses) characterized by aged oxidized aerosols.

tively). The change in slope illustrates the transformation from fresh (less oxygenated) biomass burning aerosols to aged, more oxidized particles (Alfarra et al., 2006; Jimenez et al., 2009; Ng et al., 2010; Takegawa et al., 2006a, b; Zhang et al., 2005). The $\mathrm{m} / \mathrm{z}, 44$ contributes about $6 \%$ of the total organics in the burning event, in good agreement with previews studies reporting the $m / z 44$ to be about $5 \%$ to the total organics for wood burning (Alfarra et al., 2006). He et al. (2010) reported that the abundance of the $m / z 44$ of the OA for biomass burning emissions is between 0.02 and 0.05 .

Oxygenated organic aerosol components (OOA) can be divided into two major groups according to the level of volatility and degree of oxidation (Jimenez et al., 2009; Lanz et al., 2007). Ng et al. (2010) defines the more oxidized component (higher $f 44$ ) as low-volatility OOA ( $f 44=0.17 \pm 0.04$ LV-OOA) while the less oxidized component (lower $f 44$ ) is referred to as semi-volatile OOA ( $f 44=0.07 \pm 0.04, \mathrm{SV}$ OOA). $\mathrm{Ng}$ et al. (2010) suggested that the ratio $f 44 / f 43$ can be used to estimate the degree of oxidation and volatility. High $f 44 / f 43$ indicates LV-OOA while low ratio of $f 44 / f 43$ is an indication of SV-OOA. Figure 7 shows the $f 44$ plotted as a function of the $f 43$, demonstrating two distinct populations: the burning event (Period A), and the following day (Period B).

$\mathrm{Ng}$ et al. (2010) examined organic aerosols from different sites including ground and flight data, HULIS (humiclike substances) and fulvic acid samples. The red triangular shown in Fig. 7, represents the area to which most measurements are confined. $\mathrm{Ng}$ et al. (2010) concluded that fresh SV-OOA components appear in the lower half of the triangle, while the aged LV-OOA components concentrate in the upper half of the triangle. The results from this biomass burning event show the same tendency, meaning that the freshly 


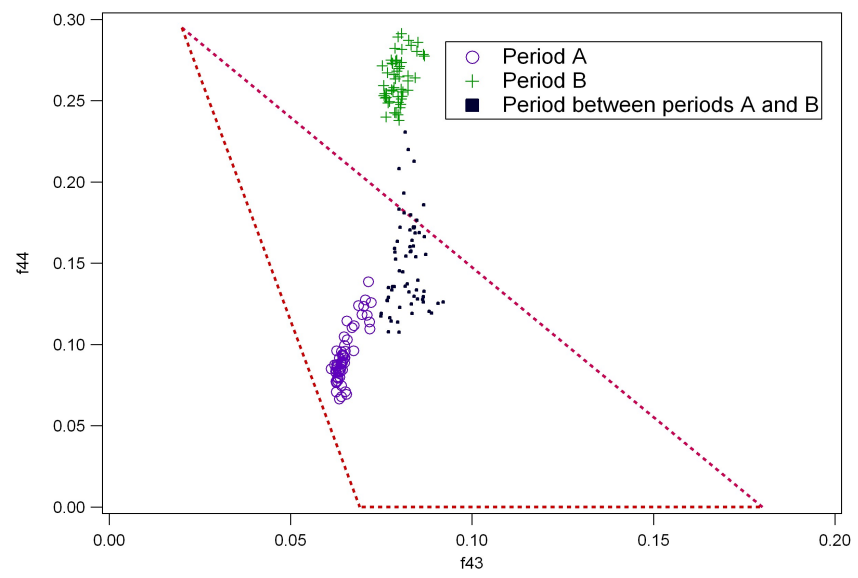

Fig. 7. $f 44$ vs. $f 43$ for Periods $\mathrm{A}$ and $\mathrm{B}$ and the transformation period between them. The area enclosed by the red triangular is adopted from $\mathrm{Ng}$ et al. (2010) and represents the common values of ambient OOA components from different sites including ground and flight data, HULIS (humic-like substances) and fulvic acid samples.

emitted aerosols (Period A) appear in the lower half of the triangle while the oxidized aerosols (Period B) appear just outside the upper part of the triangle. The $f 43$ during the burning event is consistent with the finding of He et al. (2010) which reported $f 43$ values between 0.05 and 0.10 . Nonetheless, in period $\mathrm{B}$, the $f 43$ is relatively high compared to the oxidized species examined by $\mathrm{Ng}$ et al. (2010). However, while during the $\mathrm{BB}$ emissions the abundance of $\mathrm{C}_{3} \mathrm{H}_{7}^{+}$was lower than that of $\mathrm{C}_{2} \mathrm{H}_{3} \mathrm{O}^{+}$, during period $\mathrm{B}$ most of the $m / z, 43$ is contributed by $\mathrm{C}_{2} \mathrm{H}_{3} \mathrm{O}^{+}$suggesting that the aerosol have been oxidized.

The $m / z 57$ is a typical fragment of saturated hydrocarbon compounds $\left(\mathrm{C}_{4} \mathrm{H}_{9}^{+}\right)$or long alkyl chains $\left(\mathrm{C}_{3} \mathrm{H}_{5} \mathrm{O}^{+}\right)$. The $m / z$ 57 is presented in Fig. 8 as a function of the total organics signal. The slopes in this graph, similarly to Fig. 6, are an estimation of the percentage of the $m / z 57$ from the total organic signal. Figure 8 shows a decrease in the percentage of the $\mathrm{m} / \mathrm{z}, 57$ at the day after the burning indicated by the slope of Period B $(0.02 \pm 0.001)$ which is lower compared to Period A $(0.04 \pm 0.0001)$. According to He et al. (2010) the signal abundances of the $\mathrm{m} / \mathrm{z}, 57$ for biomass burning emissions lies between 0.02 and 0.06 , which is significantly lower than the vehicle exhaust and plastic burning ratios.

Previous studies showed that for BB abundance of $\mathrm{C}_{4} \mathrm{H}_{9}^{+}$ is similar to or even lower than that of $\mathrm{C}_{3} \mathrm{H}_{5} \mathrm{O}^{+}$(Aiken et al., 2009; He et al., 2010).

In this study, a decrease in the percentage of the $\mathrm{m} / \mathrm{z} 57$ can indicate a change of freshly emitted aerosols to oxidized aerosols, since the burning event is characterized by $76 \%$ $\left(\mathrm{C}_{4} \mathrm{H}_{9}^{+}\right)$compared to period $\mathrm{B}$ in which the $\left(\mathrm{C}_{4} \mathrm{H}_{9}^{+}\right)$is reduced to around $60 \%$. There is an increase in the $\mathrm{C}_{3} \mathrm{H}_{5} \mathrm{O}^{+}$ component at period $\mathrm{B}$ which is an additional indication for

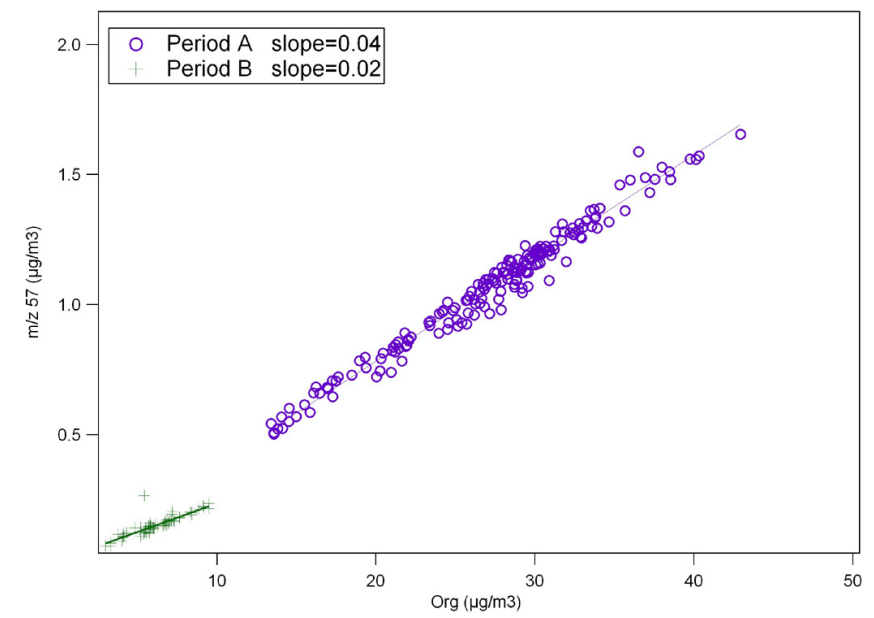

Fig. 8. $m / z 57$ mass versus the total organic mass for the two periods: Period A (marked by purple circles) represents freshly emitted aerosols. Period B (marked by green crosses) represents aged oxidized aerosols.

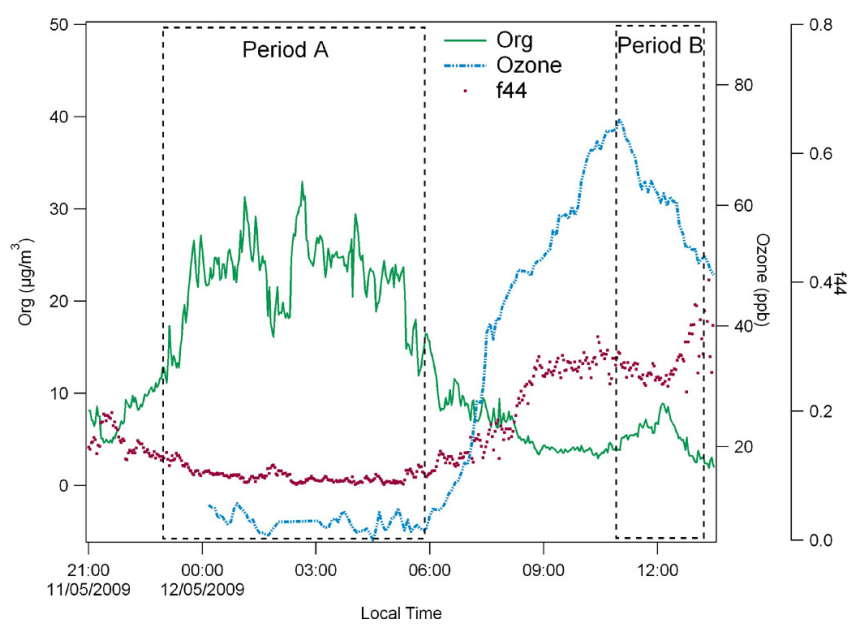

Fig. 9. The organic mass concentration, $f 44$ and the ozone concentration as a function of local time including the burning event and the day after at noon time. Photochemical production of ozone and oxidation lead to higher $f 44$ values during the day following the burning.

oxidation. The high percentage of the $\mathrm{C}_{4} \mathrm{H}_{9}^{+}$ion in the burning event may be attributed to a possible contribution from traffic-related emissions.

Figure 9 shows the variation of the organics mass and the $m / z 44$ normalized by the total organics ( $f 44)$ during the burning event and the following day. This data was obtained using the AMS and plotted together with the ozone concentration (obtained by an air monitoring station located about $800 \mathrm{~m}$ from the aerosol sampling site). The $f 44$ as well as the ozone concentration are nearly constant during the burning event, which took place during the night. The change in the aerosol chemical composition begins with the sunrise 
(around 06:00 a.m. 12 May 2009), together with an increase in ozone concentration due to photochemical ozone production. The normalized $\mathrm{m} / \mathrm{z} 44$ maintains a high level with the increase in ozone concentration. However, around noon there is a moderate decrees in $f 44$, presumably due to the observed peak in the total particulate organic matter (which will be explained in detail).

A delay in time between the peak in the ozone concentration and the second peak of organics is also observed (Period B). This could be explained as a part of an aging process. The total aging process can be divided into two parts; the first is during the creation of ozone and the second which is due to the interaction of the ozone (and presumably $\mathrm{OH}$ ) with the biomass burning aerosol and gas phase organics that lead to an increase of the organic matter. The increase in ozone following sunrise (around 06:00 a.m.) initiates photochemical smog and an increase in number concentration of the aerosols. At the same time, the oxidation process of biomass burning aerosols begins, as indicated by the increase in the $f 44$. Later, oxidized gas phase semi-volatile species adsorb on the aged biomass burning aerosols resulting in an increase of the aerosol phase organic matter (Fig. 9 12:00 a.m. 12 May 2009) and in the $f 44$. This possibly explains the time lag between the ozone concentration peak and the organics mass concentration peak. The aerosols in period $\mathrm{B}$ are assumed to have the same source (either from the bonfires around the measurement site or from bonfires in more distant areas). The measured wind speed was relatively low during most of the event as well as in the following morning (Fig. 1). The wind is coming from urban areas, in which many bonfires took place. In addition Fig. 1 shows a constant barometric pressure. Moreover, the $\mathrm{m} / \mathrm{z}, 60$ (which is used as a marker for biomass burning) was detected at high levels in period $\mathrm{B}$, further supporting the assumption that we see aged BB aerosols. However, there could be presence of mixed population of aerosols in period $\mathrm{B}$ or changes in the ambient temperature (causing changes in the partitioning of semi-volatiles). Nonetheless, the peak in the aerosol concentration, as well as the peak in the organics at the day after, is not correlated to rush hour of traffic (06:00-09:00 a.m.).The station is located close to a main road.

\section{Physical aging of biomass burning aerosols}

\subsection{Number size distribution}

Figure 10 shows the total particle concentration measured by the SMPS and plotted with the total mass of organics measured by the AMS and the ozone concentration. During Period $\mathrm{A}$, the total particle number concentration and the mass of the organics behave in a similar way. However, in Period $\mathrm{B}$, which is dominated by aged aerosols, the particle number concentration peak and the peak in the mass concentration of the organics do not occur at the same time. The peak in the

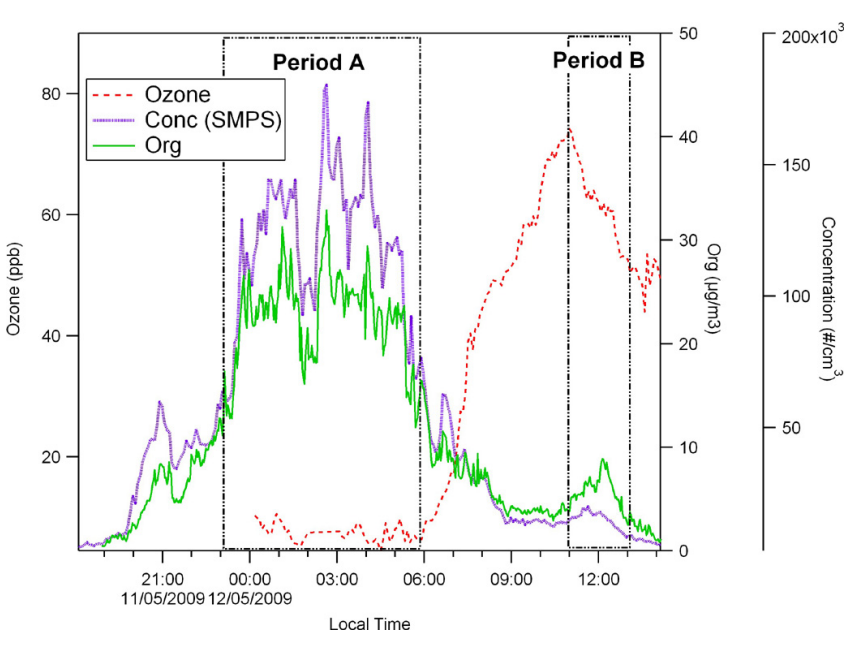

Fig. 10. The organics mass, the total concentration of the SMPS $\left(\# \mathrm{~cm}^{-3}\right)$ and ozone concentration (ppb) plotted as a function of local time, during the burning event (period A) and the following day (period B).

aerosol number concentration follows the ozone peak, suggesting that there is some formation of new particles, possibly by photochemical reactions. New particle formation by photochemical oxidation and an increase in the concentration of OA by a factor of 1.5 to 2.8 after several hours of exposure to $\mathrm{OH}$ was also reported in previous studies (Grieshop et al., 2009). This increase in the OA was explained by the oxidation of low-volatility organic vapors (Grieshop et al., 2009). The ozone concentration during Period $B$ was on average $60 \mathrm{ppb}$. As mentioned before, explanation could be the presence of a mixed population of aerosols or changes in the ambient temperature (causing changes in the partitioning of semi-volatiles). Nonetheless, the peak in the aerosol concentration, as well as the peak in the organics at the day after, is not correlated to rush hour of traffic (06:00-9:00 a.m.). The station is located close to a main road.

Photochemical production of ozone and $\mathrm{OH}$ is also accompanied by formation of semi-volatile organic species and growth to larger aerosols by condensation of additional secondary material. In this process, the size of the particles as well as the density is expected to change (Dinar et al., 2008). This assumption is supported by the increase in the mass of the organic as seen in Fig. 9.

Figure 11 shows the evolution of the SMPS size distributions normalized to the maximum concentration; the organics and $f 44$ are presented as a reference point. The BB event, as measured by the SMPS, has an average mode diameter of $86 \pm 8 \mathrm{~nm}$ compared to period $\mathrm{B}$ in which the diameter increases to $114 \pm 7 \mathrm{~nm}$. The increase in the mode of the size distributions seen in the SMPS are further evidence for the aging process. This shift in the particle diameter can be attributed to traffic soot as well. However, in Fig. 11 it can be seen that the $f 44$ signal increases with the particle diameter 


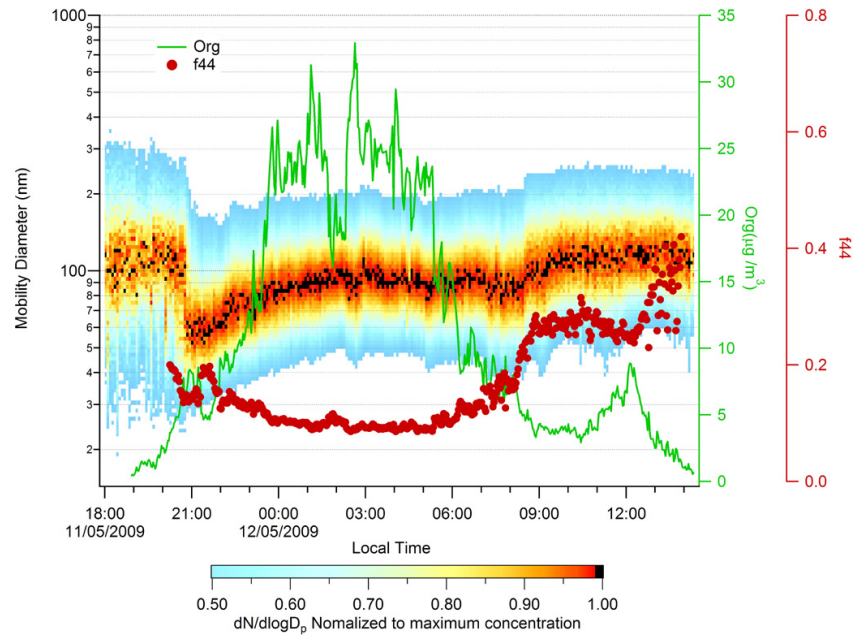

Fig. 11. The SMPS size distributions normalized to the maximum concentration, the organics and $f 44$ are presented as a function of time.

indicating condensation/coagulation due to particle and gas oxidation. In previous studies, the aerosol size distribution was shown to evolve with time, the count mean radius continuously increased as the aerosol aged (Dubovik et al., 2002; Grieshop et al., 2009). This process was claimed to be strongly affected by both coagulation and condensation (Reid et al., 2005). In addition, it can be seen that the diameter decreases at the beginning of the burning event, the aerosol population before 19:30 LT (local time) is a mixture of wood burning aerosols and traffic soot.

\subsection{Optical properties}

The effective broad band refractive index (EBRI) of the aerosols was retrieved using the WELAS as outlined in Flores et al. (2009) In general, the retrieval algorithm relies on aligning mobility size distribution (obtained by SMPS, assuming spherical particles) with the WELAS-derived optical size distribution (assuming a refractive index of PSL). The size distributions from the SMPS were corrected by accounting the loses through the inlet and tubing as was calculated by the particle loss calculator (von der Weiden et al., 2009). The EBRI is the refractive index that minimizes the difference between the size distribution measured by the SMPS and the WELAS, in other words; the EBRI is the refractive index the WELAS would have had to be calibrated with in order to size the particles correctly. Since the EBRI was developed for homogeneous spherical particles (Flores et al., 2009) we expect large errors when the aerosol is not dominated by one species. Figure 12 depicts the real and imaginary parts of the complex EBRI as a function of time. In addition the organic mass signal is presented as a reference to the timeline of the event and the day after. Due to instrumental problems a significant portion of the burning peak itself was not measured

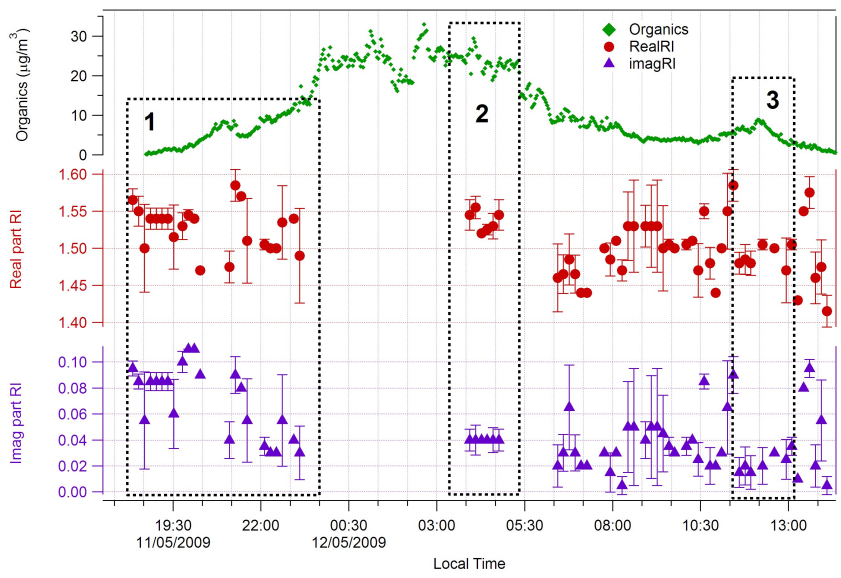

Fig. 12. Time series of the Real and imaginary components of the effective broadband refractive index (EBRI). The total organic mass is plotted to serve as a reference point. The burning event began at around 18:00 h local time. Period 1 is mostly open fires, Period 2 smoldering phase, and Period 3 is during the peak of photochemical processing.

by the WELAS. Nevertheless, the beginning (open fires) and the end (smoldering) of the burning event (Period 1 and 2 respectively) can be analyzed in comparison to the day following the burning (Period 3).

At the first period of Fig. 12 (Period 1), which is dominated by flaming, the EBRI is highly variable. It varies from a minimum value of 1.47 to a maximum of 1.59 for the real part of the RI, and from a minimum value of 0.03 to a maximum value of 0.11 for the imaginary part. This variability can be attributed to a mixed aerosol populations, one from the open fires and the other from the ambient pollution aerosols. Yamasoe et al. (1998), based on sun photometer retrievals, reported a real part of the refractive index ranging between 1.5 and 1.6 for wavelengths of $438,670,870$, and $1020 \mathrm{~nm}$ occurring mainly in flaming conditions.

During the extensive smoldering smoke event (Period 2), the EBRI is stable with an average of $m=1.54 \pm 0.01+$ $0.04 i \pm 0.01$. Wandinger et al. (2002) reported complex refractive indices ranging from 1.56 to 1.66 for the real part and 0.05 to 0.07 for the imaginary part at wavelengths between 320 and $1064 \mathrm{~nm}$, for measurements upwind of forest fires in northern Canada (at low RH conditions) (Wandinger et al., 2002).

The aerosols in our case were measured without drying them. The relative humidity at the site of the campaign during the burning event reached a maximum value of $85 \%$. Nonetheless, Hand et al. (2010) observed no significant changes in the scattering coefficient of fresh smoke at RH lower than $80 \%$. Our results are slightly lower (for both the real and imaginary part) than those reported by Wandinger et al. (2002), suggesting some water uptake by the $\mathrm{BB}$ aerosol, but the difference can also be attributed to a 
different mixture of the fuel and other ambient aerosols. On the other hand, the retrieved EBRI is higher than the average RI for biomass burning aerosol in high relative humidity conditions, as measured in the Amazon, with an average RI of $m=1.41+0.013 i$ at $545 \mathrm{~nm}$ (Guyon et al., 2003).

The day following the fires, in which the RH decrees to $50-60 \%$, there is a clear decreasing trend in the imaginary part of the EBRI. Also the real part of the EBRI is lower than for the burning event, but with more variations. The change in the real part can result from the presence of a mixed population of aerosols, traces of water due to more hydrophilic aerosols or aging. Previous studies in southern Africa have shown that the single scattering albedo increases with the aging process of the aerosol, which includes changes in the aerosol chemical composition and shape (Abel et al., 2003; Haywood et al., 2003). The aged biomass burning aerosols are less absorbing than the freshly emitted aerosols. Specifically, during noon the day after the burning event (Part 3) the average EBRI retrieved is $m=1.49( \pm 0.01)+0.02 i( \pm 0.01)$. Johnson et al. (2008) derived a complex refractive index for aged biomass burning aerosol of $n=1.54+0.045 i$, and Haywood et al. (2003) reported a value of $m=1.54+0.018 i$ at $550 \mathrm{n} \mathrm{m}$. Our values for the real part of the RI are slightly lower and the imaginary part falls in between, but Johnson el al. (2008) result was influence by the presence of dust and Haywood et al. (2003) performed most of their measurements over the Atlantic Ocean. Moreover, our results can be slightly influence by traffic aerosols as our measurements took place in an urban area.

\section{Conclusions}

We studied the chemical and physical evolution of biomass burning aerosols, during an extensive nationwide biomass burning event and during the following day. The study was conducted in the Middle East area (in Israel). High levels of PAHs and BB markers were measured by an AMS. The stable meteorological conditions combined with the presence of BB markers and PAHs in the aerosol population of the day after the burning event was used as evidence of the same population of aerosols. The average total concentration of the PAHs measured during the burning event was about $341 \mathrm{ngm}^{-3}$ suggesting that such BB events can have a significant impact on human health.

The photochemical aging process of the aerosols was followed by separating the organics into the LV-OOA and SVOOA components. The aging phases were examined in terms of $f 44, f 43$ and $f 57$. During the day following the burning high $f 44$ to $f 43$ ratio and relatively low $f 57$ (around 0.02) were observed, indicating more SV-OOA due to the oxidation process of the aerosols. Additional indication for the aging process is the shift in the size distribution, the mobility diameter for the burning event was measured to be $86( \pm 8) \mathrm{nm}$ compared to period B in which the diameter increases to 114 $( \pm 7) \mathrm{nm}$.
Moreover, a second increase in the organic mass concentration in the day following the event was observed, probably due to oxidation by ozone and $\mathrm{OH}$ that started at sunrise. This is indicated by the increase in the $f 44$, followed by the increase in the ozone concentration. We assume that another process is occurring simultaneously, less volatile species from VOC oxidation which condense on the present aerosols. As a result an increase in both the mode diameter and the organics mass is observed. These processes can be alternatively explained by the presence of a mixed population of aerosols at noon time after the event or different ambient temperature (causing changes in the partitioning of semi-volatiles).

The aging is also associated with changes in the optical properties of the aerosols. The broad band refractive index was retrieved using a white light aerosol spectrometer. It was found that the aerosol absorption decreased with the aging process. The EBRI of the day following the burning event was $m=1.49( \pm 0.01)+0.02 i( \pm 0.01)$ while during the smoldering phase it was $m=1.54( \pm 0.01)+0.04 i$ $( \pm 0.00)$, and for an aerosol population dominated by open fires $m=1.53( \pm 0.03)+0.07 i( \pm 0.03)$.

This study demonstrates how chemical aging can affect both the chemical and physical properties of aerosol, and that this process should be included in regional and global models. The study also shows that such event can pose potential health hazard due to high levels of PAHs.

Acknowledgements. This research was partially funded by a grant from the Israel Science Foundation (grant \# 196/08). The authors also acknowledge a grant from Israeli Science Foundation (technology program \#1722/07); the German Israeli Science Foundation (contract No. I-899-228.10/2005) and the Max Planck Institute internal funding. The authors acknowledge Miri Trainic, Hanan Levy, and Avi Lavy for their support in the measurements and fruitful discussions. We thank Johannes Schneider for his valuable help, and appreciate the technical help with the AMS software of Donna Sueper and Ingrid Ulbrich. The authors will also like to thank Andre Prevot and Maarten Heringa for their valuable comments. Y.R. acknowledges support by the Helen and Martin Kimmel Award for Innovative Investigation.

Edited by: A. Petzold

\section{References}

Abel, S. J., Haywood, J. M., Highwood, E. J., Li, J., and Buseck, P. R.: Evolution of biomass burning aerosol properties from an agricultural fire in Southern Africa, Geophys. Res. Lett., 30, 1783, doi:10.1029/2003GL017342, 2003.

Aiken, A. C., Salcedo, D., Cubison, M. J., Huffman, J. A., DeCarlo, P. F., Ulbrich, I. M., Docherty, K. S., Sueper, D., Kimmel, J. R., Worsnop, D. R., Trimborn, A., Northway, M., Stone, E. A., Schauer, J. J., Volkamer, R. M., Fortner, E., de Foy, B., Wang, J., Laskin, A., Shutthanandan, V., Zheng, J., Zhang, R., Gaffney, J., Marley, N. A., Paredes-Miranda, G., Arnott, W. P., Molina, L. T., Sosa, G., and Jimenez, J. L.: Mexico City aerosol analysis during 
MILAGRO using high resolution aerosol mass spectrometry at the urban supersite (T0) - Part 1: Fine particle composition and organic source apportionment, Atmos. Chem. Phys., 9, 66336653, doi:10.5194/acp-9-6633-2009, 2009.

Alfarra, M. R., Coe, H., Allan, J. D., Bower, K. N., Boudries, H., Canagaratna, M. R., Jimenez, J. L., Jayne, J. T., Garforth, A. A., Li, S. M., and Worsnop, D. R.: Characterization of urban and rural organic particulate in the lower Fraser valley using two aerodyne aerosol mass spectrometers, Atmos. Environ., 38, 57455758, 2004.

Alfarra, M. R., Paulsen, D., Gysel, M., Garforth, A. A., Dommen, J., Prvt, A. S. H., Worsnop, D. R., Baltensperger, U., and Coe, H.: A mass spectrometric study of secondary organic aerosols formed from the photooxidation of anthropogenic and biogenic precursors in a reaction chamber, Atmos. Chem. Phys., 6, 52795293, doi:10.5194/acp-6-5279-2006, 2006.

Alfarra, M. R., Prevot, A. S. H., Szidat, S., Sandradewi, J., Weimer, S., Lanz, V. A., Schreiber, D., Mohr, M., and Baltensperger, U.: Identification of the mass spectral signature of organic aerosols from wood burning emissions, Environ. Sci. Technol., 41, 57705777, 2007.

Allan, J. D., Delia, A. E., Coe, H., Bower, K. N., Alfarra, M. R., Jimenez, J. L., Middlebrook, A. M., Drewnick, F., Onasch, T. B., Canagaratna, M. R., Jayne, J. T., and Worsnop, D. R.: A generalised method for the extraction of chemically resolved mass spectra from aerodyne aerosol mass spectrometer data, J. Aerosol. Sci., 35, 909-922, 2004.

Andreae, M. O. and Merlet P.Emission of trace gases and aerosols from biomass burning, Global Biochem. Cy., 15(4), 955-966, doi:10.1029/2000GB001382, 2001.

Asgharian, B., Hofman, W., and Bergmann, R.: Particle deposition in a multiple-path model of the human lung, Aerosol Sci. Technol., 34, 332-339, 2001.

bin Abas, M. R., Oros, D. R., and Simoneit, B. R. T.: Biomass burning as the main source of organic aerosol particulate matter in Malaysia during haze episodes, Chemosphere, 55, 1089-1095, 2004

Bond, T. C., Streets D. G., Yarber, K. F., Nelson, S. M., Woo, J. M., and Klimont, Z.: A technology-based global inventory of black and organic carbon emissions from combustion. J. Geophys. Res, 109, D14203, doi:10.1029/2003JD003697, 2004.

Bolling, A. K., Pagels, J., Yttri, K. E., Barregard, L., Sallsten, G., Schwarze, P. E., and Boman, C.: Health effects of residential wood smoke particles: the importance of combustion conditions and physicochemical particle properties, Part. Fibre Toxicol., 6(29), doi:10.1186/1743-8977-6-29, 2009.

DeCarlo, P. F., Kimmel, J. R., Trimborn, A., Northway, M. J., Jayne, J. T., Aiken, A. C., Gonin, M., Fuhrer, K., Horvath, T., Docherty, K. S., Worsnop, D. R., and Jimenez, J. L.: Field-deployable, high-resolution, time-of-flight aerosol mass spectrometer, Anal. Chem., 78, 8281-8289, 2006.

Dinar, E., Anttila, T., and Rudich, Y.: CCN activity and hygroscopic growth of organic aerosols following reactive uptake of ammonia, Environ. Sci. Technol., 42, 793-799, 2008.

Dubovik, O., Holben, B., Eck, T. F., Smirnov, A., Kaufman, Y. J., King, M. D., Tanre, D., and Slutsker, I.: Variability of absorption and optical properties of key aerosol types observed in worldwide locations, J. Atmos. Sci., 59, 590-608, 2002.

Dzepina, K., Arey, J., Marr, L. C., Worsnop, D. R., Sal- cedo, D., Zhang, Q., Onasch, T. B., Molina, L. T., Molina, M. J., and Jimenez, J. L.: Detection of particle-phase polycyclic aromatic hydrocarbons in Mexico City using an aerosol mass spectrometer, Int. J. Mass. Spectrom., 263, 152-170, doi:10.1016/j.ijms.2007.01.010, 2007.

Flores, J. M., Trainic, M., Borrmann, S., and Rudich, Y.: Effective broadband refractive index retrieval by a white light optical particle counter, Phys. Chem. Chem. Phys., 11, 7943-7950, 2009.

Grieshop, A. P., Logue, J. M., Donahue, N. M., and Robinson, A. L.: Laboratory investigation of photochemical oxidation of organic aerosol from wood fires 1: measurement and simulation of organic aerosol evolution, Atmos. Chem. Phys., 9, 1263-1277, doi:10.5194/acp-9-1263-2009, 2009.

Gustafsson, O., Krusa, M., Zencak, Z., Sheesley, R. J., Granat, L., Engstrom, E., Praveen, P. S., Rao, P. S. P., Leck, C., and Rodhe, H.: Brown Clouds over South Asia: Biomass or Fossil Fuel Combustion?, Science, 323, 495-498, 2009.

Guyon, P., Boucher, O., Graham, B., Beck, J., Mayol-Bracero, O. L., Roberts, G. C., Maenhaut, W., Artaxo, P., and Andreae, M. O.: Refractive index of aerosol particles over the Amazon tropical forest during LBA-EUSTACH 1999, J. Aerosol Sci., 34, 883 907, 2003.

Hand, J. L. and Kreidenweis, S. M.: A new method for retrieving particle refractive index and effective density from aerosol size distribution data, Aerosol Sci. Technol., 36, 1012-1026, 2002.

Hand, J. L., Day, D. E., McMeeking, G. M., Levin, E. J. T., Carrico, C. M., Kreidenweis, S. M., Malm, W. C., Laskin, A., and Desyaterik, Y.: Measured and modeled humidification factors of fresh smoke particles from biomass burning: role of inorganic constituents, Atmos. Chem. Phys., 10, 6179-6194, doi:10.5194/acp10-6179-2010, 2010.

Haywood, J. M., Osborne, S. R., Francis, P. N., Keil, A., Formenti, P., Andreae, M. O., and Kaye, P. H.: The mean physical and optical properties of regional haze dominated by biomass burning aerosol measured from the C-130 aircraft during SAFARI 2000, J. Geophys. Res.-Atmos., 108(D13), 8473, doi:10.1029/2002JD002226, 2003.

He, L.-Y., Lin, Y., Huang, X.-F., Guo, S., Xue, L., Su, Q., Hu, M., Luan, S.-J., and Zhang, Y.-H.: Characterization of highresolution aerosol mass spectra of primary organic aerosol emissions from Chinese cooking and biomass burning, Atmos. Chem. Phys., 10, 11535-11543, doi:10.5194/acp-10-11535-2010, 2010.

Hedberg, E., Kristensson, A., Ohlsson, M., Johansson, C., Johansson, P. A., Swietlicki, E., Vesely, V., Wideqvist, U., and Westerholm, R.: Chemical and physical characterization of emissions from birch wood combustion in a wood stove, Atmos. Environ., 36, 4823-4837, 2002.

Herndon, S. C., Onasch, T. B., Wood, E. C., Kroll, J. H., Canagaratna, M. R., Jayne, J. T., Zavala, M. A., Knighton, W. B., Mazzoleni, C., Dubey, M. K., Ulbrich, I. M., Jimenez, J. L., Seila, R., de Gouw, J. A., de Foy, B., Fast, J., Molina, L. T., Kolb, C. E., and Worsnop, D. R.: Correlation of secondary organic aerosol with odd oxygen in Mexico City, Geophys. Res. Lett., 35, L15804, doi:10.1029/2008GL034058, 2008.

Jacobson, M. Z.: Isolating nitrated and aromatic aerosols and nitrated aromatic gases as sources of ultraviolet light absorption, J. Geophys. Res.-Atmos., 104, 3527-3542, 1999.

Jimenez, J. L., Canagaratna, M. R., Donahue, N. M., Prevot, A. S. H., Zhang, Q., Kroll, J. H., DeCarlo, P. F., Allan, J. D., Coe, 
H., Ng, N. L., Aiken, A. C., Docherty, K. S., Ulbrich, I. M., Grieshop, A. P., Robinson, A. L., Duplissy, J., Smith, J. D., Wilson, K. R., Lanz, V. A., Hueglin, C., Sun, Y. L., Tian, J., Laaksonen, A., Raatikainen, T., Rautiainen, J., Vaattovaara, P., Ehn, M., Kulmala, M., Tomlinson, J. M., Collins, D. R., Cubison, M. J., Dunlea, E. J., Huffman, J. A., Onasch, T. B., Alfarra, M. R., Williams, P. I., Bower, K., Kondo, Y., Schneider, J., Drewnick, F., Borrmann, S., Weimer, S., Demerjian, K., Salcedo, D., Cottrell, L., Griffin, R., Takami, A., Miyoshi, T., Hatakeyama, S., Shimono, A., Sun, J. Y., Zhang, Y. M., Dzepina, K., Kimmel, J. R., Sueper, D., Jayne, J. T., Herndon, S. C., Trimborn, A. M., Williams, L. R., Wood, E. C., Middlebrook, A. M., Kolb, C. E., Baltensperger, U., and Worsnop, D. R.: Evolution of Organic Aerosols in the Atmosphere, Science, 326, 1525-1529, 2009.

Johnson, B. T., Osborne, S. R., Haywood, J. M., and Harrison, M. A. J.: Aircraft measurements of biomass burning aerosol over West Africa during DABEX, J. Geophys. Res.-Atmos., 113, D00C06, doi:10.1029/2007JD009451, 2008.

Kiehl, J. T.: Twentieth century climate model response and climate sensitivity, Geophys. Res. Lett., 34, L22710, doi:10.1029/2007GL031383, 2007.

Koren, I., Kaufman, Y. J., Remer, L. A., and Martins, J. V.: Measurement of the effect of Amazon smoke on inhibition of cloud formation, Science, 303, 1342-1345, 2004.

Lanz, V. A., Alfarra, M. R., Baltensperger, U., Buchmann, B., Hueglin, C., and Prévôt, A. S. H.: Source apportionment of submicron organic aerosols at an urban site by factor analytical modelling of aerosol mass spectra, Atmos. Chem. Phys., 7, 1503-1522, doi:10.5194/acp-7-1503-2007, 2007.

Lelieveld, J., Berresheim, H., Borrmann, S., Crutzen, P. J., Dentener, F. J., Fischer, H., Feichter, J., Flatau, P. J., Heland, J., Holzinger, R., Korrmann, R., Lawrence, M. G., Levin, Z., Markowicz, K. M., Mihalopoulos, N., Minikin, A., Ramanathan, V., de Reus, M., Roelofs, G. J., Scheeren, H. A., Sciare, J., Schlager, H., Schultz, M., Siegmund, P., Steil, B., Stephanou, E. G., Stier, P., Traub, M., Warneke, C., Williams, J., and Ziereis, H.: Global air pollution crossroads over the Mediterranean, Science, 298, 794-799, 2002.

Matthew, B. M., Middlebrook, A. M., and Onasch, T. B.: Collection efficiencies in an Aerodyne Aerosol Mass Spectrometer as a function of particle phase for laboratory generated aerosols, Aerosol Sci. Technol., 42, 884-898, 2008.

Murphy, D. M., Cziczo, D. J., Froyd, K. D., Hudson, P. K., Matthew, B. M., Middlebrook, A. M., Peltier, R. E., Sullivan, A., Thomson, D. S., and Weber, R. J.: Single-particle mass spectrometry of tropospheric aerosol particles, J. Geophys. Res.-Atmos., 11, D23S32, doi:10.1029/2006JD007340, 2006.

Ng, N. L., Canagaratna, M. R., Zhang, Q., Jimenez, J. L., Tian, J., Ulbrich, I. M., Kroll, J. H., Docherty, K. S., Chhabra, P. S., Bahreini, R., Murphy, S. M., Seinfeld, J. H., Hildebrandt, L., Donahue, N. M., DeCarlo, P. F., Lanz, V. A., Prvt, A. S. H., Dinar, E., Rudich, Y., and Worsnop, D. R.: Organic aerosol components observed in Northern Hemispheric datasets from Aerosol Mass Spectrometry, Atmos. Chem. Phys., 10, 46254641, doi:10.5194/acp-10-4625-2010, 2010.

Pope, C. A.: What do epidemiologic findings tell us about health effects of environmental aerosols?, J. Aerosol Med., 13, 335354, 2000.

Pope, C. A.: Air pollution and health - Good news and bad, New
Engl. J. Med., 351, 1132-1134, 2004.

Pöschl, U.: Formation and decomposition of hazardous chemical components contained in atmospheric aerosol particles, J. Aerosol Med., 15, 203-212, 2002.

Reid, J. S., Koppmann, R., Eck, T. F., and Eleuterio, D. P.: A review of biomass burning emissions part II: intensive physical properties of biomass burning particles, Atmos. Chem. Phys., 5, 799825, doi:10.5194/acp-5-799-2005, 2005.

Rudich, Y., Donahue, N. M., and Mentel, T. F.: Aging of organic aerosol: Bridging the gap between laboratory and field studies, Annu. Rev. Phys. Chem., 58, 321-352, 2007.

Sarnat, J. A., Moise, T., Shpund, J., Yang, L., Pachon, J. E., Qasrawi, R., Abdeen, Z., Brenner, S., Nassar, K., Saleh, R., and Schauer, J. J.: Assessing the spatial and temporal variability of fine particulate matter components in Israeli, Jordanian, and Palestinian cities, Atmos. Environ., 44, 2383-2392 2010.

Schauer, C., Niessner, R., and Pöschl, U.: Polycyclic aromatic hydrocarbons in urban air particulate matter: Decadal and seasonal trends, chemical degradation, and sampling artifacts, Environ. Sci. Technol., 37, 2861-2868, 2003.

Schkolnik, G., Falkovich, A. H., Rudich, Y., Maenhaut, W., and Artaxo, P.: New analytical method for the determination of levoglucosan, polyhydroxy compounds, and 2-methylerythritol and its application to smoke and rainwater samples, Environ. Sci. Technol., 39, 2744-2752, 2005.

Spracklen, D. V., Logan, J. A., Mickley, L. J., Park, R. J., Yevich, R., Westerling, A. L., and affe, D. A.: Wildfires drive interannual variability of organic carbon aerosol in the Western US in summer, Geophys. Res. Lett., 34, L16816, doi:10.1029/2007GL030037, 2007.

Takegawa, N., Miyazaki, Y., Kondo, Y., Komazaki, Y., Miyakawa, T., Jimenez, J. L., Jayne, J. T., Worsnop, D. R., Allan, J. D., and Weber, R. J.: Characterization of an Aerodyne Aerosol Mass Spectrometer (AMS): Intercomparison with other aerosol instruments, Aerosol Sci. Technol., 39, 760-770, 2005.

Takegawa, N., Miyakawa, T., Kondo, Y., Blake, D. R., Kanaya, Y., Koike, M., Komazaki, Y., Miyazaki, Y., Shimono, A., and Takeuchi, T.: Evolution of submicron organic aerosol in polluted air exported from Tokyo, Geophys. Res. Lett., 33, L15814, doi:10.1029/2006GL025815, 2006a.

Takegawa, N., Miyakawa, T., Kondo, Y., Jimenez, J. L., Zhang, Q., Worsnop, D. R., and Fukuda, M.: Seasonal and diurnal variations of submicron organic aerosol in Tokyo observed using the Aerodyne aerosol mass spectrometer, J. Geophys. Res.-Atmos., 111, D11206, doi:10.1029/2005JD006515, 2006b.

Vione, D., Maurino, V., Minero, C., Pelizzetti, E., Harrison, M. A. J., Olariu, R. I., and Arsene, C.: Photochemical reactions in the tropospheric aqueous phase and on particulate matter, Chem. Soc. Rev., 35, 441-453, 2006.

von der Weiden, S.-L., Drewnick, F., and Borrmann, S.: Particle Loss Calculator - a new software tool for the assessment of the performance of aerosol inlet systems, Atmos. Meas. Tech., 2, 479-494, doi:10.5194/amt-2-479-2009, 2009.

Wandinger, U., Müller, D., Bockmann, C., Althausen, D., Matthias, V., Bösenberg, J., Weiss, V., Fiebig, M., Wendisch, M., Stohl, A., and Ansmann, A.: Optical and micro10 physical characterization of biomass-burning and industrial-pollution aerosols from multiwavelength lidar and aircraft measurements, J. Geophys. Res.Atmos., 107(D21), 8125, doi:10.1029/2000JD000202, 2002. 
Wichmann, H. E, Spix, C., Tuch, T., Wölke, G., Peters, A., Heinrich, J., Kreyling, W. G., and Heyder, J.: Fine and Ultrafine Particles in Erfut, Germany, Part I: Role of Particle Number and Particle Mass, Health Effects Institute, Cambridge MA 98, 2000.

Yamasoe, M. A., Kaufman, Y. J., Dubovik, O., Remer, L. A., Holben, B. N., and Artaxo, P.: Retrieval of the real part of the refractive index of smoke particles from Sun/sky measurements during SCAR-B, J. Geophys. Res.-Atmos., 103, 31893-31902, 1998.

Zhang, Q., Worsnop, D. R., Canagaratna, M. R., and Jimenez, J. L.: Hydrocarbon-like and oxygenated organic aerosols in Pittsburgh: insights into sources and processes of organic aerosols, Atmos. Chem. Phys., 5, 3289-3311, doi:10.5194/acp-5-32892005, 2005a.

Zhang, Q., Alfarra, M. R., Worsnop, D. R., Allan, J. D., Coe, H., Canagaratna, M. R., and Jimenez, J. L.: Deconvolution and quantification of hydrocarbon-like and oxygenated organic aerosols based on aerosol mass spectrometry, Environ. Sci. Technol., 39, 4938-4952, 2005b.
Zhang, Q., Jimenez, J. L., Canagaratna, M. R., Allan, J. D., Coe, H., Ulbrich, I., Alfarra, M. R., Takami, A., Middlebrook, A. M., Sun, Y. L., Dzepina, K., Dunlea, E., Docherty, K., DeCarlo, P. F., Salcedo, D., Onasch, T., Jayne, J. T., Miyoshi, T., Shimono, A., Hatakeyama, S., Takegawa, N., Kondo, Y., Schneider, J., Drewnick, F., Borrmann, S., Weimer, S., Demerjian, K., Williams, P., Bower, K., Bahreini, R., Cottrell, L., Griffin, R. J., Rautiainen, J., Sun, J. Y., Zhang, Y. M., and Worsnop, D. R.: Ubiquity and dominance of oxygenated species in organic aerosols in anthropogenically-influenced Northern Hemisphere midlatitudes, Geophys. Res. Lett., 34, L13801, doi:10.1029/2007GL029979, 2007. 